Fig. I is a radioautograph of the ionogram. The free phosphate band has been allowed to run off the anode end of the paper. The exact correspondence of the radioactive bands from the three di-isopropyl phosphoryl-enzymes indicates that the hydrolysates contain identical peptidos of phosphoserine which are entirely different from those derived from ovalbumin. The structure of the different peptide bands is not certain at present but is under investigation. From the number present and their identity in the three enzymes it is probably safe to conclude that elastase, like trypsin and chymotrypsin contains the sequence Gly-Asp-Ser-Gly around its reactive serine residue.

Doparment of Biachemistry, University of Cambridge (Graat Britain)

B. S. HARTLEY

M. A. Nalghton

F. S.MAER*

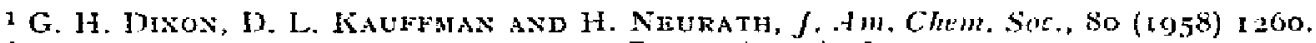

IT. TURBA AND G. GUXDLACH, Biochem. $7 ., 327$ (195.5) I 86 .

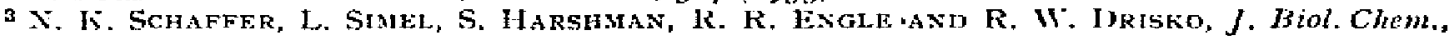
$22,3(1957) 197$.

1. E. Toshlaxd axd MI. J. Erivin, J. Am, Chesh. Soc., 79 (1057) 2657.

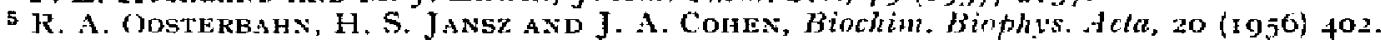

6 J. A. Gladxer Axd K. L.ki, J. Am. Chom. Soc., So (1958) 1204.

7 M. A. NAUGhTON AND F. SANGer, Biohom. J.,70 (1958) \& $\mathrm{P}$.

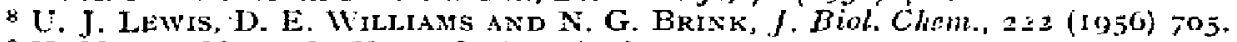

9 H. MICHL, Mometsh. Cheirh., 82 (1951) 489 .

Reccived November 27 th, 1958

* Membor of the external staff of the Medical Research Council.

\title{
A simplified spectrophotometric determination of ester groups in lipids
}

Our İaboratory's need for an extremely simple yet highly sensitive and accurate assay of lipid ester groupings in large numbers of chromatographic samples prompted the development of the method reported here. It is based on a hydroxylaminolysis in which an ester reacts with alkaline hydroxylamine to form a hydroxamic acid; the latter forms a purple iron-chelate complex in the presence of acid ferric perchlorate. This method is a modification of more laborious procedures ${ }^{1-3}$, and its range extends to $4.00 \mu$ equiv. ester.

A standard curve was determined on samples of tristearin, tripalmitin, methyl stearate, or methyl palmitate (California Foundation for Biochemical Research). The veighed lipid was dissolved in Fisher reagent-grade chioroform. Aliquots of the standards were pipetted into test tubes $\left(8_{5} \times I_{5} \mathrm{~mm}\right)$, and the solvent removed under infrared lamps. Acetone (about $0.5 \mathrm{ml}$ ) was routinely added to all samples at this point to insure complete removal of the chloroform. The acetone was again evaporated under infrared lamps.

Reagents: Stoch Ferric Perchlorate $5 \mathrm{~g}$ ferric perchlorate (nonyellow) were dissolved in Io $\mathrm{ml}_{70}^{\circ} \mathrm{HClO}_{4}$ and $\mathrm{ro} \mathrm{ml}$ water, then diluted to roo ml with cold absolute ethano! (stored in refrigerator); Reagent Forric Porchlovate. $4 \mathrm{ml}$ stock ferric perchlorrate and $3 \mathrm{ml} 70 \% \mathrm{HClO}_{4}$ were diluted to $100 \mathrm{ml}$ with cold absolute ethanol; Alkuliue Hydroxylamine. Equal vols, of a $4 \%$ ethanolic hydroxylamine solution (2.0 g 
dissolved in $2.5 \mathrm{ml} \mathrm{H}_{2} \mathrm{O}$, diluted to $50 \mathrm{ml}$ with absolute ethanol) and of an $8 \%$ ethanolic NaOH (4 $\mathrm{g}$ dissolved in $2.5 \mathrm{ml} \mathrm{H}_{2} \mathrm{O}$, diuted to $50 \mathrm{ml}$ with atsolute othanol) were mixed in a stoppered cylinder. The $\mathrm{NaCl}$ was sepilrated by centrifugation and the supernatant was decanted for use.

Procodare: (I) I ml alkaline hydroxylamine reagent (fresh daily) was added to each of the dry lipid samples. (2) The samples were placed in a water bath at $65^{\prime 2}$ for 2 min. (3) The samples were removed from the water bath and allowed to cool for $5 \mathrm{~min}$. (4) The ferric perchlorate reagent $(2.5 \mathrm{ml}$, fresh daily) was arlded to the tubes, mixed, aud after 30 min the purple color wus read in a $\mathrm{I}-\mathrm{cm}$ cuvette against a reagent blank in a Becliman $B$ spectrophotometer at $530 \mathrm{~m} \mu$. The color was stable for more than $\mathrm{x} \mathrm{h}$.

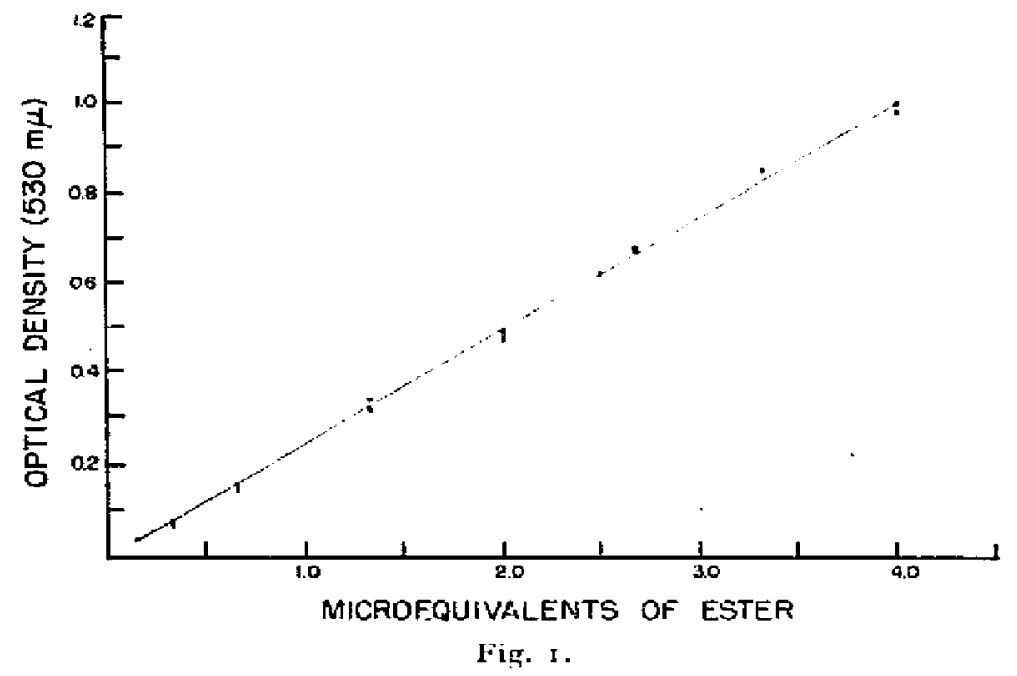

The precirion and accuracy of this method can readily be seen from the curve in Fig. I, which shows the result of duplicate determinations of ester in tristearin samples as measured on 3 different days. Ester equivalents of eripalmitin, methyl palmitate, or methyl stearate gave curves identical to that obtained with tristearin. We have also used this method successfully with lecithin samples. The actual time required to develop the purple color in 20 to 30 samples is between 15 and $z 0$ min. The metlod described avoids the time consumed in treating each sample individually ${ }^{2}$ and at the same time provides a means of determining extremely small quantities of lipid esters with excellent reproducibility.

This work was done under contract with the U. S. Atomic Encrgy Commission.
Medical Division, Oah Ridge Rintitate of Nuclear Stalies, IFRD SXYDNR Oak Rilge, Tenn. (U.S.A.) NHi.SON STFPHENS

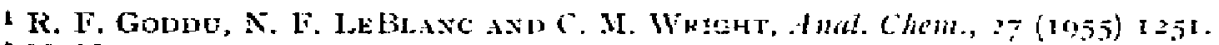

2 M. AL. RATPORT AN1 N. Wowao, J. Riol. Chen.. 217 (1055) I03.

A. R. Thonpson, tustratian ./. Si. Re'search, 3 (1050) I 25 . 


\section{The purification of renin by use of ion-exciange chromatography}

Recent advances in the preparation and uses of cellulose ion-exchange agents for the purification of proteins ${ }^{12}$ suggested their possible use in the purification of hogkidney renin.

The adsorbent chosen was DEAE-cellulose prepared according to PErERson .xi) Solner, with a capacity of $0.7^{6}$ mequiv./g. Columns with dimensions of I $2 \times 55 \mathrm{~cm}$ and hold-up vol. of $\mathrm{I} \mathrm{I} \mathrm{ml}$ were prepared from $4 \mathrm{~g}$ of the ion exchanger. Semi-pure renin was prepared from fresh hog kidneys and from desiccated hog-kidney powder by a procedure described by H.hs of al., ${ }^{4}$. These preparations were carried through five of the ten steps of their isolation procedure. The fractionations were performed in the cold room $\left(6^{\circ}\right)$, and the precipitate ohtained from Step 5 was dissolved in water and dialyzed. Aiter dialysis the dry weight of enzyme was obtained by drying to constant weight by heating to $105^{\circ}$ and cooling in a desiccator over $\mathrm{P}_{2} \mathrm{O}_{5}$. Pressor activity of the preparation was measured by injection of solutions of suitable strength intravenously into a dog anesthetized with $\mathrm{Na}$ Pentobarbital (35 $\mathrm{mg} / \mathrm{kg}$ ). A unit of renin is the quantity required to raise the mean femoral blood pressure of a dog $30 \mathrm{~mm} \mathbf{H g}$. 'The specific activity of the renin is expressed as the number: of dog units/mg protein.

The equilibrated enzyme preparation was washed into a glass column containing the exchanger which had been adjusted to $\mathrm{PH} 7.0$ by addition of $\mathrm{NaH}_{2} \mathrm{PO}_{4}$ solutions and packed with air pressure (ro lb./in. ${ }^{2}$ ) until a constant column height was obtained. The column would not run dry under gravity flow and maintained an effluent flow of two drops per minute when a total hydrostatic head of $a_{7}$ in. was employed. Gradients of salt $\left(\mathrm{NaH}_{2} \mathrm{PO}_{4}\right)$ and $\mathrm{pH}$ were employed for elution, with the addition of $\mathrm{NaCl}$ in the later stages of the elution to raise the salt concentration. Gradients were established by introducing from a separatory funnel into a constant-volume $(50 \mathrm{ml})$ mixing clamber buffer having the composition of the gradient limit. All column operations were carried out in the cold room. Individual tube collections of about $6 \mathrm{ml}$ were determined by a drop counter but the volume of each tube was measured directly.

The effluent fractions were examined for protein in a Beckman DU spectrophotoneter by measuring the absorbance at $280 \mathrm{~m}_{\mu}$. Paper-electrophoretic determinations were made on ro $\mu \mathrm{l}$ of material which was obtained by concentrating the effluent against polyvinylpyrrolidone. Gross sampling was necessary to provide sufficient protein for these analyses which were made with veronal bufier $(\mu, 0.075 ; \mathrm{pH}, 8.6)$ at rcom temperature for $16 \mathrm{~h}$ at a constant current of $6 \mathrm{~mA}$. The paper strips were stained with bromophenol blue.

Fig. I shows the elution diagram obtained when the dialyaed semi-pure renin was chromatographed on $\mathrm{DE}$-AE-cellulose. The starting buffez was $0.005 \mathrm{M} \mathrm{NaH}_{2} \mathrm{PO}_{4}$ at $\mathrm{pH} 7.0$, after which decreasing $\mathrm{pH}$ and increasing salt gratients were employed.

All effuent fractions wers assayed for protein content and enzyme activity. Fractions $4 \mathrm{I}-60$ which contained activity were combined and concentrated against polyvinylpyrolidone. This active fraction was approximately ten times as pure as the material placed on the column $i, c, 9 \mathrm{mg}$ protein was recovered containing $85 \%$ of the original activity.

The original semi-pure cenin gave an absnrption spectrum atypical for a protein 
i.e, no maximum in the ragion of $260 \mathrm{~m} \mu$ (tyrosine and tryptophan), but did give a strong absorption band between IBo and $230 \mathrm{~m} \mu(\mathrm{CO}-\mathrm{NH})$ corresponding to the $\beta$-form proposed by H.As al al.7. These authors report that these aromatic amino acids appear in high content as compared with that of other proteins, On the other hand, renin eluted from the column gave a typical $u . v$. spectrum with a maximum at $280 \mathrm{~m} \mu$. These differences were found to be dut to itcetone contamination and not to differences in precein configuration, as proposed by Hals et al., since $\mathrm{I} \mathrm{ml}$ of semi-pure enzyme contains $3.6 \mu$ moles acetone. Furthermore, serum albumin treated in like manner can be male to yield two different curte's depending upon whether acetone is present $i$, the preparation. This study then indicates that the differences observed with u.v. spectroscopy are dur. to the strong absorption of the acetonecarbonyl function in the region of $260 \mathrm{~m} \mu$.

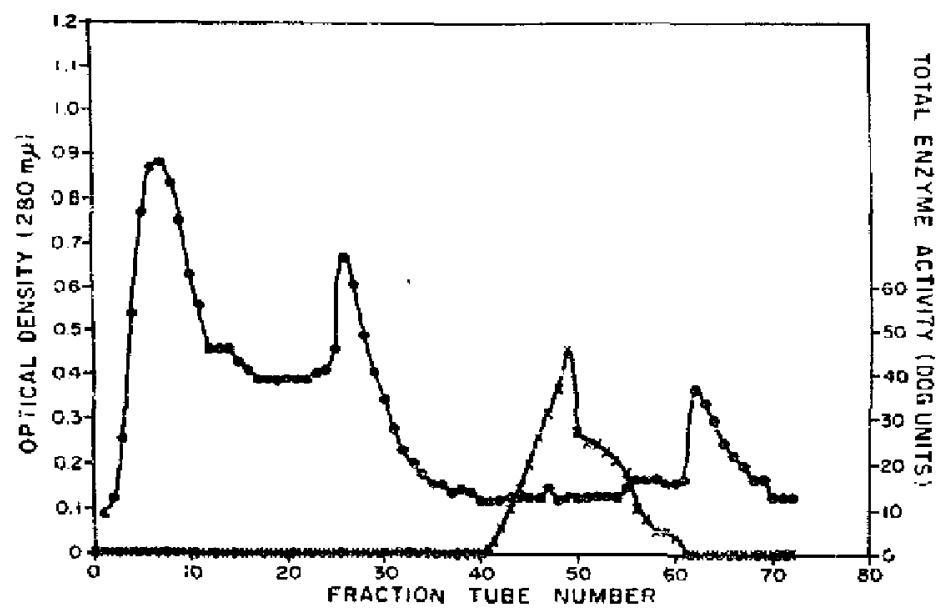

Fig. 1. Effuent diafram of semi-pure loch-kidney remin: 1eso mig dialyzed protein (430 nutsi in

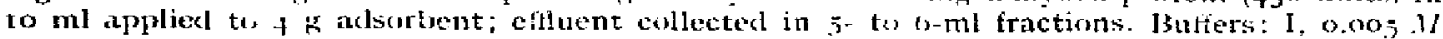

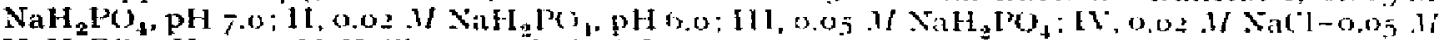

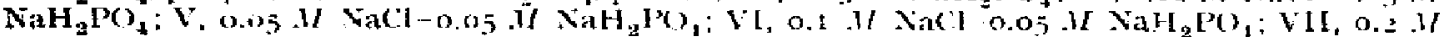

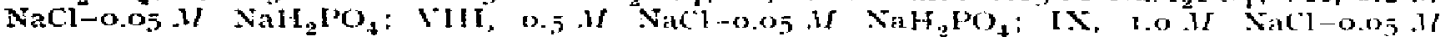

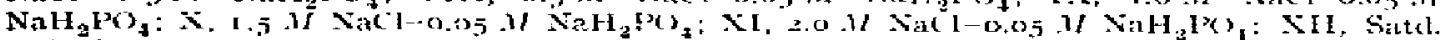

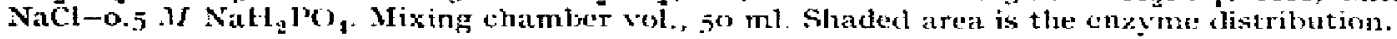

The semi-pure renin preparation gave a positive nitroprusside reaction for a sulfhydryl-containing compound while the chromatographed renin gave a negative test. The extraneous proteins in the semi-pure preparaticn may therefore be proteins having sulfhydryl groups and some of the renin present may be in the denatured form.

Paper electrophoresis at $\mathrm{pH} 8.6$ revealed the presence of two components in the eluted renin whereas the semi-pure material was composed of at least four bands.

The column charge in these studies was roo $\mathrm{mg}$ protein for $4 \mathrm{~g}$ adsorbert. This was decreased to $3 \mathrm{~g}$ exchanger and packed under ( $\mathrm{I}+.7 \mathrm{lb}$. in. ${ }^{2}$ ) air pressure with a flow rate of one drop per $2 \mathrm{~min}$. Under both conditions with different samples of enzyme the reproducibility of the positions and magnitudes of the chromatographic peaks were good. In another study the enzyme was not equilibrated to $\mathrm{pH} 7.0$ but run at $\mathrm{pH}$ 5.r, the $\mathrm{pH}$ of step 5. The effuent pattern of this was similar to that obtained with the equilibrated samples. 
An ion-exchange chromatographic technique for the purification of renin has becn described. The specific artivity of the preparation which was applied to the column was 4.3 . The eluted renin had a specific activity of 43.2 . This constitutes a Io-fold purification of renin by use of cellulose ion-exchange chromatography, with a recovery of $85 "$, of the enzyme activity.

I wish to thank Dr. Plivro Blagulek for performing the bioassays reported in this manuscript, and Dr, O. M. HELMER of Eli Lilly and Co. for generous supplies of desiccated hog-kidney powder. This worked was aided by graits from the National Heart Institute, U.S. Dept. of Health, Education and Welfare (H-25\%8c) and the Michigan Heart Association.

Hupertonsion tonit, Doparment of Internal Medicine, Mctical Sohool, "nin'ersity of Michigan.

G. lhom.s P.iss.hNiNT" Am Arbor, Mich. (C.S.A.)

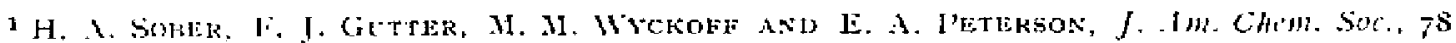
(1950) 750 .

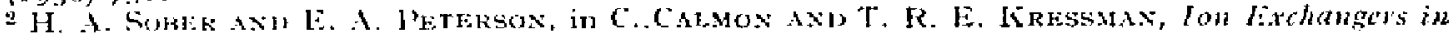

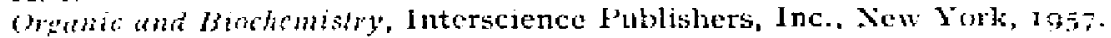

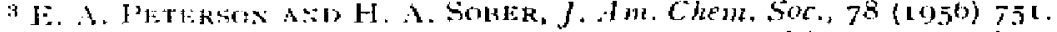

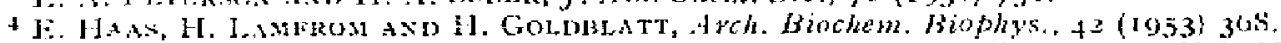

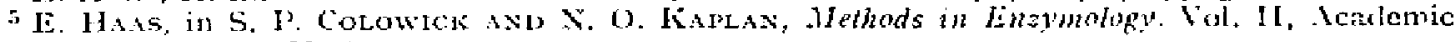
Press, Inc., New York, 1955 .

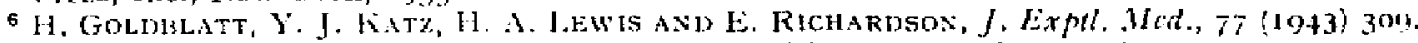

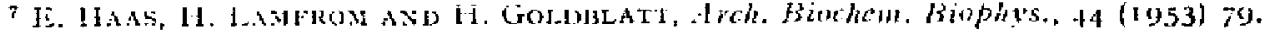

Received November 24th, 1958

- iresent adclass: l pepartment of Dermatology, Eniversity of Michigan Medical Sihool, .un Arbm, Mich.

\section{A simplified method for the purification of mushroom polyphenol oxidase}

Purification of mushroom polyphenol oxidase has been sought in this laboratory in order to pursue structural studies on this enzyme and to explore the role of tyrosine in the secondary and tertiary structure of proteins ${ }^{2-5}$. While this work was in progress,

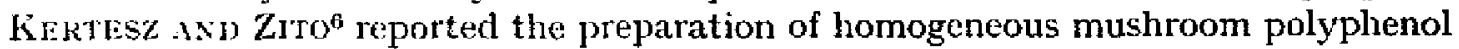
oxidase. Taking advantage of the excellent early steps of this procedure*, we have uscd chromatography on diethylaminoethyl-cellulose (DEAF-cellulose) ${ }^{7}$ as the basis for a nighly simplified method to prepare the purified enzyme in good yield. A similar chromatographic procedure for the peparation of a soluble maminalian tyrosinase was also recently reported by BROWN AND WARD ${ }^{B}$.

The yidds and steps in the method are summarized in Table $I$ and in the experimcatal scetion. After extraction and preliminary puritication through Step 4, the crude enzyme is prepared for direct chromatography by an extensive dialysis

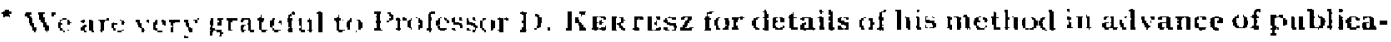
tikn. 